\title{
Interesting foliicolous fungi from Southern Western Ghats of Kerala, India
}

\author{
V.B. Hosagoudar* and Jacob Thomas
}

Tropical Botanic Garden and Research Institute, Palode, Thiruvananthapuram-695 562 (Kerala), INDIA

*Corresponding author. E-mail: vbhosagoudar@ rediffmail.com

\begin{abstract}
An account of five foliicolous fungal taxa are dealt herein. Of these, Asterina glycosmidigena, A. gymnemae, Irenopsis pavoniae, Phyllachora gymnemae infected the leaves of Glycosmis pentaphylla, Gymnema sysvestre and Pavonia sp., respectively, are described as new species while, Meliola pseudarthriaevar. indica is described as a new variety on Pseudarthria viscida. The detailed description of these taxa is supplemented with line drawings and photo plate.
\end{abstract}

Keywords: Foliicolous fungi, Asterina, Irenopsis, Phyllachora, Kerala, India

\section{INTRODUCTION}

Authors have been engaged in the study of foliicolous fungal flora of Western Ghats region of Kerala State and have made several collections of these fungi. Of these, Glycosmis pentaphylla and Gymnema sylvestre in Wayanad region, Pavoniasp. and Pseudarthria viscida from Peppara and Neyyar wildlife sanctuaries in Thiruvananthapuram were found infected with black mildew and tar spot fungi. Critical microscopic examination of the fungi revealed that they are hitherto undescribed species.

\section{Taxonomy}

1. Asterina glycosmidigena sp. nov. (Fig. 1)

Coloniae epiphyllae, tenues, ad $2 \mathrm{~mm}$ diam., confluentes. Hyphae pallide brunneae, rectae vel leniter anfractuae, irregulariter acuteque vel laxe ramosae, laxe reticulatae et formans laxe dictyonist, cellulae 12-19 x 2-5 $\mu \mathrm{m}$. Appressoria sessilia, plerumque alternata, circa $2 \%$ opposita, unicellularis, ovata, subglobosa, integra vel irregulariter sublobata, 4-10 x 4-7 $\mu \mathrm{m}$. Thyriothecia dispersa, orbicularis, saepe connata, ad $110 \mu \mathrm{m}$ diam., stellatim dehiscentes ad centre, margine crenatae; asci globosi, octospori, 50-60 $\mu \mathrm{m}$ diam.; ascosporae oblongae, conglobatae, brunneae, uniseptatae, fortiter constrictus ad septatae, 14-19 x 7-10 $\mu \mathrm{m}$, parietus glabrus.

Colonies epiphyllous, thin, up to $2 \mathrm{~mm}$ in diameter, confluent. Hyphae pale brown, straight to slightly crooked, branching irregular at acute to wide angles, loosely reticulate and form a loose mycelial net, cells 12 19 x 2-5 $\mu \mathrm{m}$. Appressoria sessile, mostly alternate, about $2 \%$ opposite, unicellular, ovate, subglobose, entire to irregularly sublobate, 4-10 x 4-7 $\mu \mathrm{m}$. Thyriothecia scattered, orbicular, often connate, up to $110 \mu \mathrm{m}$ in diameter, stellately dehisced at the centre, margin crenate; asci globose, octosporous, 50-60 $\mu \mathrm{m}$ in diameter; ascospores oblong, conglobate, brown, uniseptate, strongly constricted at the septum, 14-19 x 7-10 $\mu \mathrm{m}$, wall smooth.

Materials examined: On leaves of Glycosmis pentaphylla (Retz.) DC. \{G. cochin-chinensis sensu Gamble\} (Rutaceae), Thirunelli, Wayanad, Kerala, Feb. 14, 2009, Jacob Thomas and al TBGT 3669 (type).

The present species differs from Asterina glycosmidis Hosag. \& Rajkumar and A. banguiensis Yates known on the host genus Glycosmis in having hemispherical, broad based, entire to irregularly sublobate to lobate appressoria (Hosagoudar, 2005; Yates, 1918). Based on the line drawings, Kaul \& Nair (1988) have erroneously assigned their collection on this host from Ooty to $A$. banguiensis.

These colonies were mixed with the colonies of Meliola $\mathrm{sp}$. 2. Asterina gymnemae sp. nov. (Fig. 2)

Coloniae epiphyllae, subdensae, ad $1 \mathrm{~mm}$ diam., confluentes. Hyphae subrectae vel undulatae, opposite vel irregulariter acuteque vel laxe ramosae, laxe vel arte reticulatae, cellulae 19-34 x 2-5 $\mu \mathrm{m}$. Appressoria alternata, bi-cellula, recta vel curvula, antrorsa, 12-14 $\mu \mathrm{m}$ longa; cellulae basilares cylindraceae vel cuneatae, rectae vel anfractuae, 2-5 $\mu \mathrm{m}$ longae; cellulae apicales ovatae, globosae, angularis, sublobatae vel variae lobatae, 4-7 x 4-10 $\mu \mathrm{m}$. Thyriothecia dispersa, orbicularis, ad $150 \mu \mathrm{m}$ diam., stellatim dehiscentes ad centre, margine crenatae; asci pauci vel numerosi, globosi, octospori, 40-60 $\mu \mathrm{m}$ diam.; ascosporae conglobatae, uniseptatae, hyalinae ad initio et brunneae ad maturitatae, constrictus ad septatae, 1619 x 7-10 $\mu \mathrm{m}$, parietus glabrus.

Colonies epiphyllous, subdense, up to $1 \mathrm{~mm}$ in diameter, confluent. Hyphae substraight to undulate, branching opposite to irregular at acute to wide angles, loosely to closely reticulate, cells $19-34$ x 2-5 $\mu \mathrm{m}$. Appressoria 


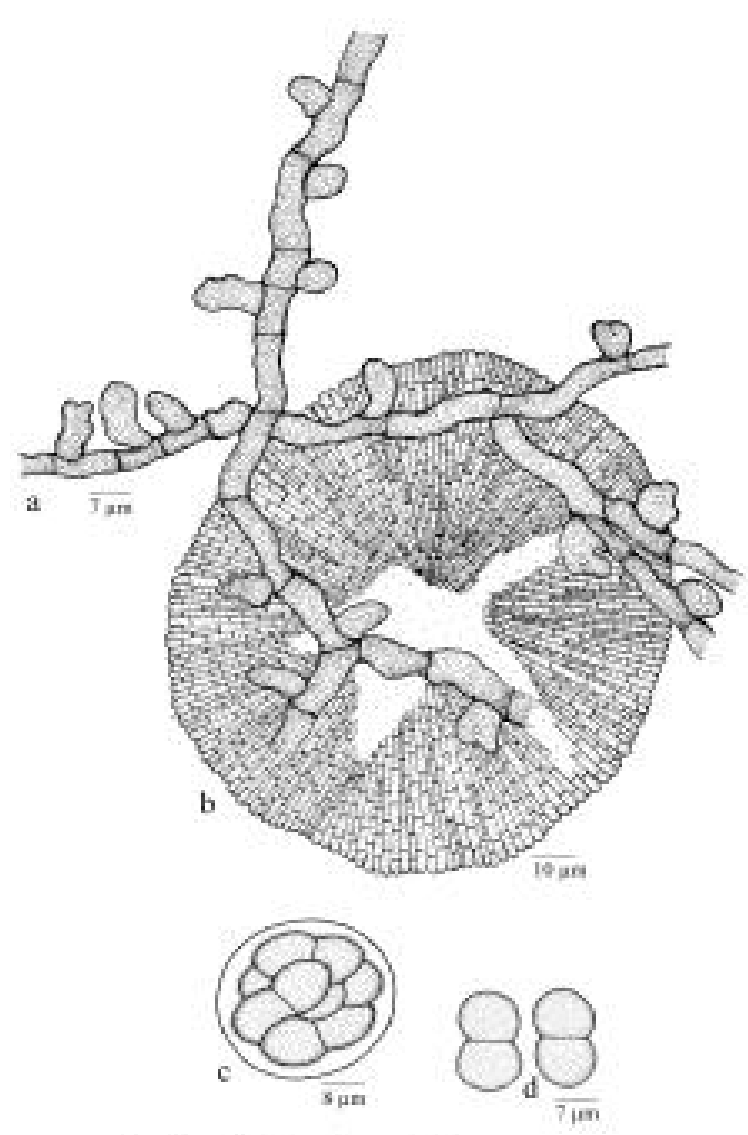

Fig. 1. Asterina glycosmidigena sp. nov. a. Appressoriate mycelium, b. Thyriothecium, c. Ascus, d. Ascospores.

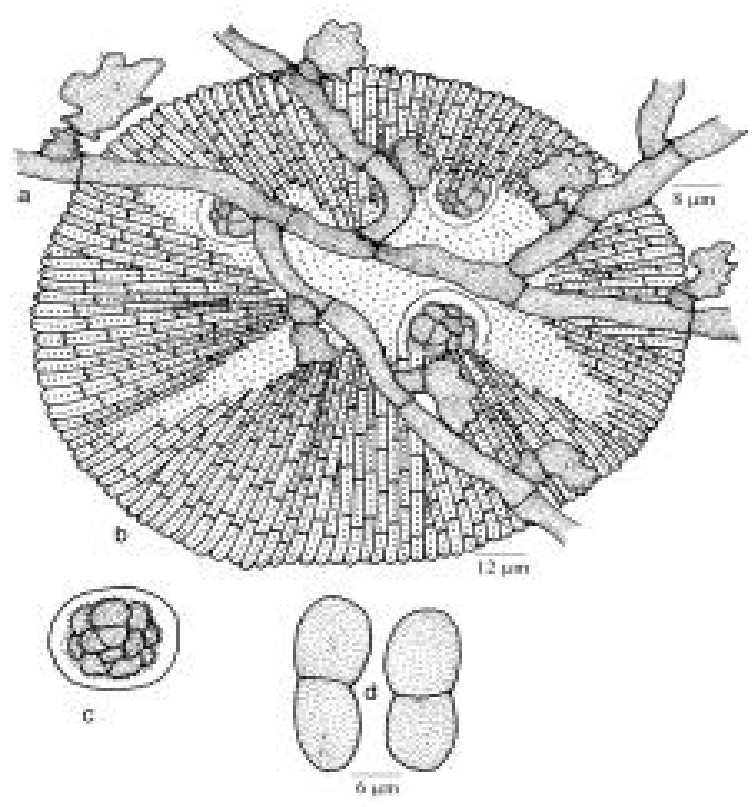

Fig. 2. Asterina gymnemae sp. nov. a. A p p ress o riate mycelium, $b$. Thyriothecium, $c$. Ascus, $d$. Ascospores.

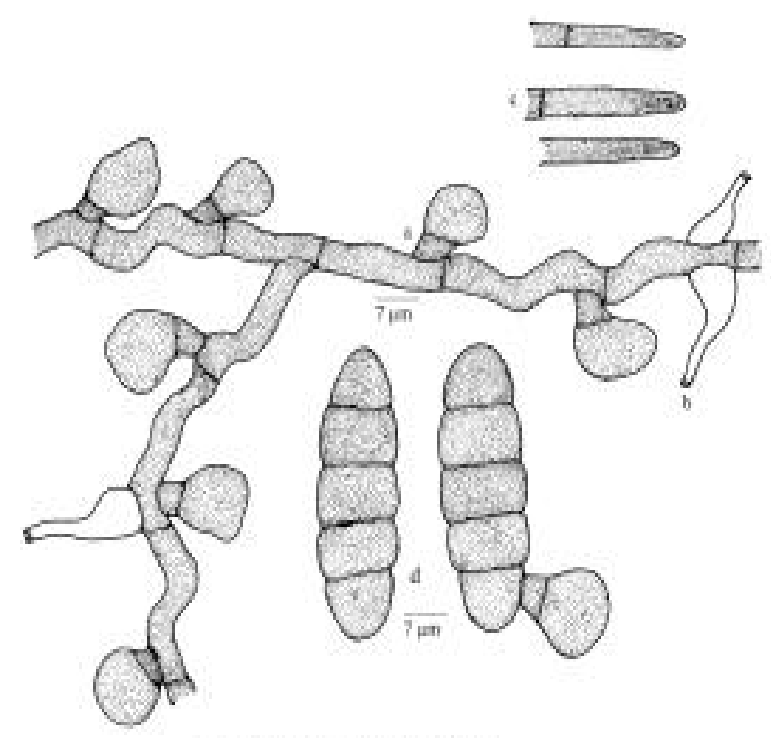

Fig. 3. Irenopsis pavoniae sp. nov. a. Appressoriate mycelium, $b$. Phialide, c. Apical portion of the perithecial setae, $d$. Ascospores.

alternate, two celled, straight to curved, antrorse, 12-14 $\mu \mathrm{m}$ long; stalk cells cylindrical to cuneate, straight to crooked, 2-5 $\mu \mathrm{m}$ long; head cells ovate, globose, angular, sublobate to variously lobate, 4-7 x 4-10 $\mu \mathrm{m}$. Thyriothecia scattered, orbicular, up to $150 \mu \mathrm{m}$ in diameter, stellately dehisced at the centre, margin crenate; asci few to many, globose, octosporous, $40-60 \mu \mathrm{m}$ in diameter; ascospores conglobate, uniseptate, initially hyaline but brown at maturity, constricted at the septum, 16-19 x 7-10 $\mu \mathrm{m}$, wall smooth.

Materials examined: On leaves of Gymnema sylvestre R. Br. (Asclepiadaceae), Thirunelli, Wayanad, Kerala, Feb. 14, 2009, Jacob Thomas and al TBGT 3667a (type).

There are six species of the genus Asterina known on the members of the family Asclepiadaceae, namely, Asterina asclepiads Hosag. and Goos (Hosagoudar and Goos, 1996), A. concinna Sydow (Sydow, 1930), A. cynanchi Hosag. and Shiburaj (Hosagoudar, 2002), A. leonensis Sydow (1938), and A. peraffinis Speg. (Theissen, 1913). Based on the character of angular to sublobate head cells and normal number of appressoria, the present species is closer to $A$. cynanchi, A. leonensis and $A$. peraffinis. The present new species differs from $A$. peraffinis in having narrow ascospores and from $A$. cynanchi in having longer ascospores. It also differs from A. leonensis in having only alternate appressoria. 3. Irenopsis pavoniae sp. nov. (Fig. 3)

Coloniae epiphyllae, tenues, ad $2 \mathrm{~mm}$ diam., confluentes. Hyphae flexuosae, opposite vel irregulariter laxe ramosae, arte reticulatae, cellulae 19-58 x 4-7 $\mu \mathrm{m}$. Appressoria alternata, vel unilateralis, antrorsa vel patentia, recta vel varie curvula, 14-19 $\mu \mathrm{m}$ longa; cellulae basilares cylindraceae vel cuneatae, 4-10 $\mu \mathrm{m}$ longae; cellulae 


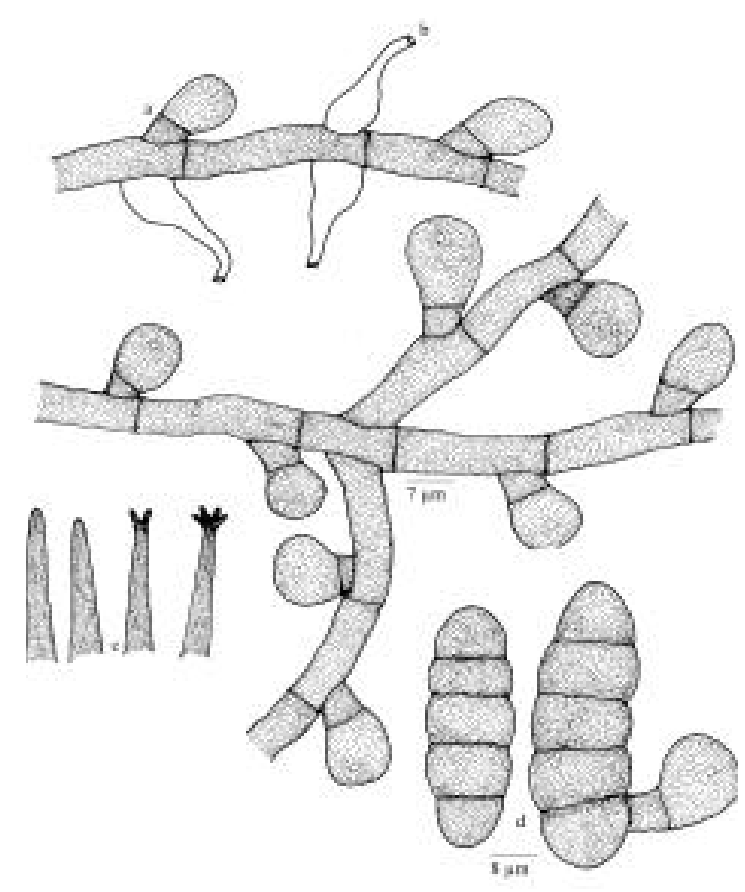

Fig. 4. Meliola pseudarthriae var. indica var. nov. a. Appressoriate mycelium, $b$. Phialide, c. Apical portion of the mycelial setae, $d$. Ascospores.

apicales ovatae vel globosae, integrae, subangularis vel sublobatae, truncatae, 9-11 × 9-12 $\mu \mathrm{m}$. Phialides appressoriis mixtus, alternata vel opposita, ampulliformes, 14-24 x 4-7 $\mu \mathrm{m}$. Perithecia dispersa vel laxe aggregata, ad $140 \mu \mathrm{m}$ diam.; setae peritheciales 10-16 numero, simplices, rectae, glabr, obtusae ad apicem, ad $120 \mu \mathrm{m}$ longae; ascosporae obovoideae vel ellipsoideae, 4-septatae, constrictus ad septatae, $31-36 \times 12-14 \mu \mathrm{m}$.

Colonies epiphyllous, thin, up to $2 \mathrm{~mm}$ in diameter, confluent. Hyphae flexuous, branching opposite to irregular at wide angles, closely reticulate, cells $19-58$ x 4$7 \mu \mathrm{m}$. Appressoria alternate, $5 \%$ unilateral, antrorse to spreading, straight to variously curved, $14-19 \mu \mathrm{m}$ long; stalk cells cylindrical to cuneate, $4-10 \mu \mathrm{m}$ long; head cells ovate to globose, entire, subangular to sublobate, truncate, 9-11 x 9-12 $\mu \mathrm{m}$. Phialides mixed with appressoria,

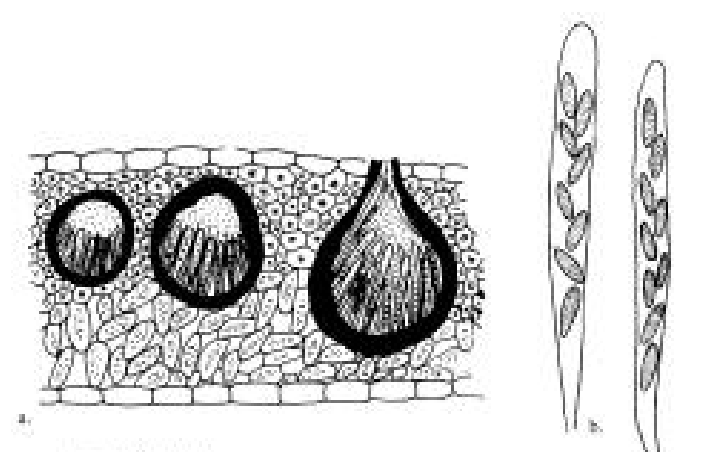

Fig. 5. Phyllachora gymnemae sp. nov. a. T.S. through the stromata showing perithecia, b. Asci with ascospores. alternate to opposite, ampulliform, 14-24 x 4-7 $\mu \mathrm{m}$. Perithecia scattered to loosely grouped, up to $140 \mu \mathrm{m}$ in diameter; perithecial setae 10-16 in number, simple, straight, smooth, obtuse at the tip, up to $120 \mu \mathrm{m}$ long; ascospores obovoidal to ellipsoidal, 4-septate, constricted at the septa, 31-36 x 12-14 $\mu \mathrm{m}$.

Materials examined: On leaves of Pavonia sp. (Malvaceae), Peppara Wildlife Sanctuary, Thiruvananthapuram, Kerala, Nov. 18, 2007 Jacob Thomas TBGT 3601 (type).

Based on the digital formula 3401.3220 , flexuous to crooked hyphae and entire to sublobate apical cells of appressoria, this species is closer toIrenopsis aciculosa (Wint.) Stev., I. sidae (Rehim) Hughes (Hansford, 1961). However, entire to angular head cells in contrast to lobate ones and obtuse tip of the perithecial setae are the distinguishing characters of this species.

\section{Meliola pseudarthriae var. indica var. nov. (Fig. 4)}

Differt a var. pseudarthriae setae myceliales cristatae vel dentatae.

Colonies epiphyllous, dense, velvety, up to $4 \mathrm{~mm}$ in diameter, confluent. Hyphae substraight to undulate, branching opposite at acute to wide angles, closely reticulate, cells $12-25$ × 6-8 $\mu \mathrm{m}$. Appressoria alternate to opposite, antrorse to spreading, straight to curved, 9-18 $\mu \mathrm{m}$ long stalk cells cylindrical to cuneate, 3-6 $\mu \mathrm{m}$ long; head cells globose to subglobose, ovate, cylindrical, entire, 6-15 x 8-14 $\mu \mathrm{m}$. Phialides mixed with appressoria, alternate to opposite, ampulliform, 14-21 x 6-8 $\mu \mathrm{m}$. Mycelial setae numerous, scattered, simple, straight to slightly curved, acute, dentate to cristate at the tip, up to $600 \mu \mathrm{m}$ long. Perithecia scattered, globose, up to $160 \mu \mathrm{m}$ in diam.; ascospores cylindrical to obovoidal, 4-septate, constricted at the septa, 35-40 x 12-16 $\mu \mathrm{m}$.

Materials examined: On leaves of Pseudarthria viscida (L) Wight and Arn. (Fabaceae), near Kombe, Neyyar Wild Life Sanctuary, Thiruvananthapuram, Kerala, March 15, 2008, Jacob Thomas TBGT 3603 (type)

Meliola pseudarthriae Hosag. and Manoj. is known on this host genus from the Western Ghats region of Kerala state (Hosagoudar, 2008). However, the new variety differs from var. pseudarthriae in having dentate to cristate mycelial setae.

\section{Phyllachora gymnemae sp. nov. (Fig. 5, Plate 1)}

Stromata epiphylla, caulicola, ad $5 \mathrm{~mm}$ diam., nitida, nigra, elevata; perithecia 1-3 per stromata, ovata, globosa vel craterviformes, ostiolata, 105-220 x 130-180 $\mu \mathrm{m}$; asci numerosi, cylindrici, paraphysati, unitunicati, ad $94 \mu \mathrm{m}$ longi et ad $12 \mu \mathrm{m}$ crassi; ascosporae uniseriatae, ovatae, hyalinae, elongatae et leniter acuminatae ad ambi apicem, 9-14 x 4-7 $\mu \mathrm{m}$.

Stromata epiphyllous, caulicolous, up to $5 \mathrm{~mm}$ in diam., shining, black, raised; perithecia 1-3 per stromata, oval, globose to craterviform, ostiolate, $105-220$ x 130-180 $\mu \mathrm{m}$; 


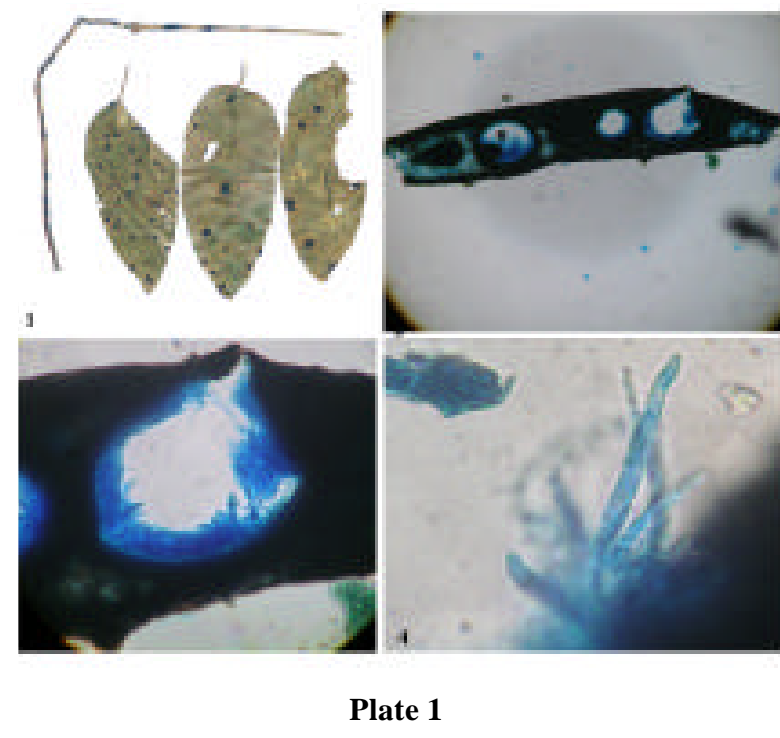

asci numerous, cylindrical, paraphysate, unitunicate, up to $94 \mu \mathrm{m}$ long and up to $12 \mu \mathrm{m}$ broad; ascospore uniseriate, oval, hyaline, elongated and slightly pointed at both ends, 9-14 x 4-7 $\mu \mathrm{m}$.

Materials examined: On leaves of Gymnema sylvestre R.Br. (Asclepiadaceae), Thirunelli, Wayanad, Kerala, Feb. 14, 2009, Jacob Thomas and al TBGT 3668 (type).

This species differs from Phyllachora ajrekari Sydow and $P$. kanyakmariana Hosag. in having ellipsoidal ascospores tapering towards both ends (Kamat et al., 1978, Hosagoudar, 1995).

\section{ACKNOWLEDGEMENTS}

We thank Dr. A. Subramoniam, Director, Tropical Botanic Garden and Research Institute, Palode for the facilities; to Ministry of Environment and Forests, New Delhi and Forest Department, Govt. Kerala, for the financial assistance and for the forest permission, respectively.

\section{REFERENCES}

Hansford, C. G. (1961). The Meliolineae. A Monograph. Sydowia. Beih., 2: 1-806.

Hosagoudar, V. B. (1995). Two new Phyllachora species from Tamil Nadu. Indian Phytopathol., 48: 213-214.

Hosagoudar, V. B. (2002). Studies on foliicolous fungi - X. Five new species and a new record.Zoos'Print J., 17: 943-948.

Hosagoudar, V. B. (2005). Studies on foliicolous fungi - XIX. Indian Phytopathol., 58: 94-204.

Hosagoudar, V. B. (2008). Meliolales of India, Vol.-II. Botanical Survey of India, pp. 390.

Hosagoudar, V. B. and Goos, R. D. (1996). Some foliicolous fungi from southern India. Mycotaxon., 59: 149-166.

Kamat, M.N., Seshadri, V.S. and Pande, A.A. (1978). A Monographic study of Indian species of Phyllachora. University of Agricultural Sciences, Hebbal, Bangalore, pp. 100.

Kaul, V. P. and Nair, L. N. (1988). Some new reports of Asterina from India, Acta Bot. Indica, 16: 227-229,

Sydow, H. 1938. Novae fungorum species-XXVI.Ann. Mycol., 36: $156-253$.

Sydow, H. (1930). Fungi Venezuelai. Ann. Mycol. 28: 29-224 Theissen, F. 1913. Dei Gattung Asterina. Bibliotheca Mycologica., 10:1-130.

Yates, H. S. (1918). Some recently collected Philippine fungiII. Philippine J. Sci., 13: 361-384. 